\title{
Character association and path analysis studies in germplasm lines of rabi sorghum (Sorghum bicolor (L.) Moench)
}

\author{
Santosh Khadakabhavi*1, G. Girish ${ }^{2}$ and Yashoda ${ }^{1}$ \\ ${ }^{1}$ Department of Genetics and Plant Breeding, University of Agricultural Sciences, Raichur- 584104 (Karnataka), \\ INDIA \\ ${ }^{2}$ Agricultural Research Station, University of Agricultural Sciences, Raichur, Gulbarga-585101 (Karnataka), INDIA \\ *Corresponding author. E-mail: santoshssk04@gmail.com
}

Received: May 9, 2016; Revised received: November 7, 2016; Accepted: January 21, 2016

\begin{abstract}
The field experiment was carried out using 121 germplasm lines of rabi sorghum to study association among the yield and its component traits, direct and indirect effects of traits on the yield. Association studies indicated that at both genotypic and phenotypic levels, panicle width $(\mathrm{rg}=0.190 ; \mathrm{rp}=0.204)$ and 1000 grain weight $(r g=0.450 ; r p=0.520)$ showed significantly positive correlation with grain yield per plant. Genotypic correlation magnitude was higher than phenotypic correlation. Partitioning of yield and yield components both at phenotypic and genotypic levels into direct and indirect effects revealed that the characters that had positive direct effects on grain yield were 1000 grain weight $(\mathrm{Ppi}=+0.3085$, $\mathrm{Pgi}=+0.4621)$, panicle length (Ppi=+0.1516, $\mathrm{Pgi}=+0.2843)$, days to maturity $(\mathrm{Ppi}=+0.1539, \mathrm{Pgi}=+0.1391)$ at both genotypic and phenotypic level. On grain yield indicating importance of these characters hence, due consideration should be given to these characters while planning a breeding strategy by utilizing rabi sorghum.
\end{abstract}

Keywords: Character association, Germ lines, Path analysis, Sorghum bicolor

\section{INTRODUCTION}

Sorghum (Sorghum bicolor (L.) Moench) is one of the major cereal crops of the Semi-Arid tropics. It is the fourth most important cereal crop following rice, wheat and maize and staple food in the semi-arid parts of the world. India is the major sorghum growing country in the world, ranks first in acreage with 6684.4 ha and second in production with $913 \mathrm{~kg} / \mathrm{ha}$ next to United States of America (FAOSTAT, 2014). Major producers of sorghum in the world are USA, India, Nigeria, China, Mexico, Sudan and Argentina. Sorghum has been classified under family Graminae, subfamily Poaceae, tribe Andropogonae, genus Sorghum, Species sorghum bicolor. Yield is a complex character, which depends upon many independent contributing characters. Knowledge of the magnitude and type of association between yield and its components themselves greatly help in evaluating the contribution of different components towards yield. Yield being a polygenic character is highly influenced by the fluctuations in environment. Hence, selection of plants based directly on yield would not be very reliable. Improvement in sorghum yield depends on the nature and extent of genetic variability, heritability and genetic advance in the base population. Besides, the information on the nature of association between yield and its components helps in simultaneous selection for many characters associated with yield improvements
(Mahajan et al., 2011).

The estimates of correlations alone may be often misleading due to mutual cancellation of component traits. So, it becomes necessary to study path coefficient analysis, which takes into account the casual relationship in addition to degree of relationship. The path coefficient analysis initially suggested by Wright (1921) and described by Dewey and $\mathrm{Lu}$ (1959) allows partitioning of correlation coefficient into direct and indirect contributions (effects) of various traits towards dependent variable and thus helps in assessing the cause-effect relationship as well as effective selection. Hence, this study was aimed to analyze and determine the traits having greater interrelationship with grain yield utilizing the correlation and path analysis.

\section{MATERIALS AND METHODS}

The present field experiment on sorghum (Sorghum bicolor L. Moench) was conducted in Agricultural Research Station, Gulbarga (Karnataka) during rabi 2011-12 and rabi 2012-13. The 121 germplasm lines include in the study were collected from Gulbarga districts of Karnataka, Bijapur, Dharwad, Coimbatore, NRC of sorghum Solapur and ICRISAT Hyderabad. The germplasm lines were evaluated in a field experiment under $11 \times 11$ simple lattice design was followed with two replications of $4 \mathrm{~m}$ length with inter row spacing of $45 \mathrm{~cm}$ and intra row spacing of $15 \mathrm{~cm}$. All 
the recommended practices were followed to raise good crop of rabi sorghum. Each row was over planted later thinned to 1 plant per hill 15 days after emergence. $50 \mathrm{~kg}$ Nitrogen per hacter and $25 \mathrm{~kg}$ Phosphorous per hacter of Diamonium phosphate was applied as basal fertilizer. All other crop cultural management practices were followed to raise successful crop.

The biometrical observations recorded on five randomly selected plants from each entry per replication. The replication wise mean values of the genotypes were subjected to statistical analysis. Observations were recorded on the following characters viz., Days to 50\% flowering, Days to Maturity, Plant height, Panicle length, stem girth, Panicle width, Grain yield per plant and 1000 grain weight.

The correlation coefficients were calculated to determine the degree of association of the yield attributes with yield and also among yield attributes themselves. The analysis of covariance was conducted by the method designed by Singh and Chaudhary (1977). Path coefficient is a standardized partial regression coefficient and as such it is a measure of direct and indirect effect of set variables as a dependent variable such as grain yield. This is done as suggested by Wright (1921) and elaborated by Dewey and Lu (1959). Knowledge of the relationship among yield components is essential for the formulation of breeding programmes aimed at achieving the desired combinations of various components of yield. The estimates of correlation coefficients among the different characters indicate the extent and direction of association. The correlation co-efficient provide a reliable measure of association among the characters and help to differentiate vital associations useful in breeding from those of the non-vital ones (Falconer, 1981). Data for all these attributes were subjected to window MSTAT computer ver 13.0 software. Abbreviations: Ppi: path phenotypic direct effect, Pgi: path genotypic direct effect, Pr: path phenotypic residual value, Gr: path genotypic residual values.

\section{RESULT AND DISCUSSION}

Correlation: Correlation coefficient is a statistical measure, which denotes the degree and magnitude of association between any two casually related variables. This association is due to pleitropic gene action or linkage or more likely both. In plant breeding correlation coefficient analysis measures the mutual relationship between two characters and it determines character association for improvement yield and other economic characters. Since the association pattern among yield components help to select the superior genotypes from divergent population based on more than one interrelated characters. Thus information on the degree and magnitude of association between characters is of prime important for the breeder to initiate any selection plan.

In the present investigation the estimates of genotypic correlation was higher than those of phenotypic correlation for most of the traits. These higher genotypic

Table 1. Genotypic correlation co-efficient between different traits in one hundred twenty one germplasm lines of sorghum.

\begin{tabular}{|c|c|c|c|c|c|c|c|c|}
\hline Character & $\begin{array}{l}\text { Days to } 50 \% \\
\text { flowering }\end{array}$ & $\begin{array}{l}\text { Days to } \\
\text { maturity }\end{array}$ & $\begin{array}{l}\text { Stem } \\
\text { girth } \\
(\mathrm{cm})\end{array}$ & $\begin{array}{l}\text { Plant } \\
\text { height } \\
\text { (cm) }\end{array}$ & $\begin{array}{l}\text { Panicle } \\
\text { length } \\
(\mathrm{cm})\end{array}$ & $\begin{array}{l}\text { Panicle } \\
\text { width } \\
\text { (cm) }\end{array}$ & $\begin{array}{l}1000 \text { grain } \\
\text { weight } \\
\text { (g) }\end{array}$ & $\begin{array}{l}\text { Grain } \\
\text { yield per } \\
\text { plant (g) }\end{array}$ \\
\hline Days to $50 \%$ flowering & 1.000 & $0.385 * *$ & 0.139 & 0.055 & -0.079 & -0.013 & $0.187 *$ & $-0.210 *$ \\
\hline Days to maturity & & 1.000 & 0.036 & $0.298 * *$ & $-0.301 * *$ & -0.107 & -0.131 & 0.150 \\
\hline Stem girth $(\mathrm{cm})$ & & & 1.000 & 0.090 & 0.010 & -0.062 & 0.067 & $0.320 * *$ \\
\hline Plant height $(\mathrm{cm})$ & & & & 1.000 & 0.098 & 0.030 & 0.155 & -0.032 \\
\hline Panicle length $(\mathrm{cm})$ & & & & & 1.000 & $0.241 * *$ & -0.099 & $0.240 * *$ \\
\hline Panicle width $(\mathrm{cm})$ & & & & & & 1.000 & -0.107 & $0.190 *$ \\
\hline 1000 grain weight $(\mathrm{g})$ & & & & & & & 1.000 & $0.450 * *$ \\
\hline Grain yield per plant $(\mathrm{g})$ & & & & & & & & 1.000 \\
\hline
\end{tabular}

* - Significant at $5 \%$ probability; ** - Significant at $1 \%$ probability

Table 2. Phenotypic correlation co-efficient between different traits in one hundred twenty one germplasm lines of sorghum.

\begin{tabular}{|c|c|c|c|c|c|c|c|c|}
\hline Character & $\begin{array}{l}\text { Days to } 50 \% \\
\text { flowering }\end{array}$ & $\begin{array}{l}\text { Days to } \\
\text { maturity }\end{array}$ & $\begin{array}{l}\text { Stem } \\
\text { girth } \\
(\mathrm{cm}) \\
\end{array}$ & $\begin{array}{l}\text { Plant } \\
\text { height } \\
\text { (cm) }\end{array}$ & $\begin{array}{l}\text { Panicle } \\
\text { length } \\
(\mathrm{cm}) \\
\end{array}$ & $\begin{array}{l}\text { Panicle } \\
\text { width } \\
(\mathrm{cm})\end{array}$ & $\begin{array}{l}1000 \\
\text { grain } \\
\text { weight (g) } \\
\end{array}$ & $\begin{array}{l}\text { Grain } \\
\text { yield per } \\
\text { plant (g) }\end{array}$ \\
\hline Days to $50 \%$ flowering & 1.000 & $0.409 * *$ & 0.104 & 0.040 & -0.060 & -0.036 & 0.059 & $-0.250^{* *}$ \\
\hline Days to maturity & & 1.000 & 0.049 & $0.304 * *$ & $-0.198 *$ & -0.123 & -0.028 & $-0.270 * *$ \\
\hline Stem girth $(\mathrm{cm})$ & & & 1.000 & 0.002 & 0.014 & -0.050 & 0.042 & 0.125 \\
\hline Plant height (cm) & & & & 1.000 & 0.096 & 0.025 & 0.112 & 0.132 \\
\hline Panicle length (cm) & & & & & 1.000 & $0.173 *$ & 0.105 & 0.147 \\
\hline Panicle width $(\mathrm{cm})$ & & & & & & 1.000 & $-0.192 *$ & $0.204 *$ \\
\hline 1000 grain weight $(\mathrm{g})$ & & & & & & & 1.000 & $0.520 * *$ \\
\hline Grain yield per plant (g) & & & & & & & & 1.000 \\
\hline
\end{tabular}

* - Significant at $5 \%$ probability; ** - Significant at $1 \%$ probability 
Table 3. Direct and indirect effects on grain yield at genotypic level in one hundred twenty one germplasm lines of sorghum.

\begin{tabular}{lllllllll}
\hline Character & $\begin{array}{l}\text { Days to } \\
\mathbf{5 0 \%} \\
\text { flowering }\end{array}$ & $\begin{array}{l}\text { Days to } \\
\text { maturity }\end{array}$ & $\begin{array}{l}\text { Stem } \\
\text { girth }(\mathbf{c m})\end{array}$ & $\begin{array}{l}\text { Plant } \\
\text { height } \\
\text { (cm) }\end{array}$ & $\begin{array}{l}\text { Panicle } \\
\text { length } \\
\text { (cm) }\end{array}$ & $\begin{array}{l}\text { Panicle } \\
\text { width } \\
\text { (cm) }\end{array}$ & $\begin{array}{l}\text { 1000 } \\
\text { grain } \\
\text { Wt }(\mathbf{g})\end{array}$ & $\begin{array}{l}\text { Correlation } \\
\text { with grain } \\
\text { yield }(\mathbf{g})\end{array}$ \\
\hline Days to 50\% flowering & -0.1145 & -0.0041 & -0.0356 & -0.0061 & 0.0093 & 0.0005 & -0.0198 & $-0.2100^{*}$ \\
Days to maturity & 0.0050 & 0.1391 & -0.0418 & 0.0415 & -0.0419 & 0.0524 & -0.0207 & 0.1500 \\
Stem girth (cm) & -0.0326 & 0.0316 & -0.2550 & 0.0085 & -0.0104 & -0.0190 & -0.0349 & $0.3200^{* *}$ \\
Plant height (cm) & -0.0007 & -0.0040 & 0.0011 & -0.0133 & -0.0012 & -0.0007 & -0.0021 & -0.0320 \\
Panicle length (cm) & -0.0216 & -0.0796 & 0.0263 & 0.0245 & 0.2843 & 0.0740 & -0.0248 & $0.2400^{* *}$ \\
Panicle width (cm) & 0.0003 & -0.0264 & -0.0127 & -0.0039 & -0.0897 & -0.0702 & 0.0051 & $0.1900^{*}$ \\
1000 grain weight (g) & 0.1145 & -0.0987 & 0.1202 & 0.1027 & -0.0621 & -0.1479 & 0.4621 & $0.4500^{* *}$ \\
\hline
\end{tabular}

* - Significant at $5 \%$ probability, Residual effect $0.372, * *$ - Significant at $1 \%$ probability,

Table 4. Direct and indirect effects on grain yield at phenotypic level in one hundred twenty one germplasm lines of sorghum.

\begin{tabular}{lcccccccc}
\hline Character & $\begin{array}{c}\text { Days to } \\
\mathbf{5 0 \%} \\
\text { flowering }\end{array}$ & $\begin{array}{c}\text { Days to } \\
\text { maturity }\end{array}$ & $\begin{array}{c}\text { Stem } \\
\text { girth } \\
\text { (cm) }\end{array}$ & $\begin{array}{c}\text { Plant } \\
\text { height } \\
\text { (cm) }\end{array}$ & $\begin{array}{c}\text { Panicle } \\
\text { length } \\
\text { (cm) }\end{array}$ & $\begin{array}{c}\text { Panicle } \\
\text { width } \\
\text { (cm) }\end{array}$ & $\begin{array}{c}\mathbf{1 0 0 0} \\
\text { grain } \\
\text { weight (g) }\end{array}$ & $\begin{array}{c}\text { Correlation } \\
\text { with grain } \\
\text { yield (g) }\end{array}$ \\
\hline Days to 50\% flowering & -0.0788 & -0.0840 & -0.0094 & -0.0150 & 0.0010 & 0.0010 & -0.0054 & $-0.2500^{* *}$ \\
Days to maturity & 0.0714 & 0.1539 & -0.0007 & 0.0421 & -0.0027 & 0.0017 & -0.0002 & $-0.2700^{* *}$ \\
Stem girth (cm) & -0.0005 & 0.0002 & -0.0050 & 0.0001 & -0.0001 & -0.0003 & -0.0001 & 0.1250 \\
Plant height (cm) & 0.0036 & 0.0129 & -0.0004 & 0.0858 & 0.0086 & 0.0013 & 0.0092 & 0.1320 \\
Panicle length (cm) & -0.0070 & -0.0240 & 0.0013 & 0.0123 & 0.1516 & 0.0141 & 0.0009 & 0.1470 \\
Panicle width (cm) & 0.0016 & -0.0047 & -0.0022 & -0.0006 & -0.0545 & -0.1387 & -0.0004 & $0.2040^{*}$ \\
1000 grain weight (g) & 0.0175 & -0.0036 & 0.0095 & 0.0825 & 0.0585 & 0.0483 & 0.3085 & $0.5200^{* *}$ \\
\hline
\end{tabular}

* - Significant at $5 \%$ probability, ** - Significant at $1 \%$ probability, Residual effect $=0.464$

values whenever observed were contributed to the relative stability of the genotypes. Thus trait with higher genetic correlation may throw light on validity of selection for those traits.

Correlation studies revealed that, the characters viz., Days to 50 per cent flowering, days to maturity and panicle length had positive and significant association with days to maturity $\left(\mathrm{rg}=+0.385^{*}, \mathrm{rp}=+0.409^{* *}\right)$, plant height $\left(\mathrm{rg}=+0.298^{* *}, \mathrm{rp}=+0.304^{* *}\right)$ and panicle width $(\mathrm{rg}=+0.241 * *, \mathrm{rp}=+0.173 *)$ respectively at both genotypic and phenotypic levels. In addition, panicle width and 1000 grain weight showed significantly positive correlation with grain yield per plant $(\mathrm{rg}=+0.190$ * $\left.\mathrm{rp}=+0.204^{*}\right)$ and $\left(\mathrm{rg}=+0.450^{* *}, \mathrm{rps}=+0.520^{* *}\right)$ at both genotypic and phenotypic levels. It indicates that genotypes with bold seed produces higher grain yield. It attracts consumer's preference. Hence selection for bold grain size helps the farmers to cultivate bold seeded types it will fetch higher market price for their produce.

At genotypic level, Days to $50 \%$ flowering with 1000 grain weight $\left(\mathrm{rg}=+0.187^{*}\right)$ had showed positive significant correlation similar results are in line with Prabhakar et al. (2001) reported positive significant correlation with days to $50 \%$ flowering, Umakanth et al.(2005) repoted positive significant correlation for the traits plant height, panical length and 1000 grain weight, Patil et al. (2009) reported positive correlation for panical length and Warkad et al. (2010) reported positive correlation for various characters viz., days to $50 \%$ flowering, plant height, panical length, panical width, 1000 grain weight, stem girth and grain yield. Whereas, days to maturity with panicle length $\left(\mathrm{rg}=-0.301^{* *}\right)$ and days to $50 \%$ flowering with grain yield per plant had showed negative significant correlation. These results are in confirmation with the findings of Ezeaku et al. (2005); Khaled et al. (2014); Warkad et al. (2010) reported negative significant correlation for the same traits. The results are represented in the table 1 .

At phenotypic level, days to maturity with panicle length $\left(\mathrm{rp}=-0.198^{*}\right)$, panicle width with 1000 grain weight $(\mathrm{rp}=-0.192 *)$ had shown negative correlation. Whereas, with grain yield per plant days to $50 \%$ flowering and days to maturity had shown negative significance. These findings are in line with Muhammad et al. (2000) reported negative significant correlation for days to $50 \%$ flowering and 1000 grain weight and Kengra et al. (2006) reported negative significant correlation for days to $50 \%$ flowering. Negative correlation was desirable for days to $50 \%$ flowering, as less number of days to flowering reduces the crop duration, this helpful in terms of economic cultivation of sorghum crop. More over it helps the crop to escape terminal drought, hence the selection can be practiced for early flowering genotypes with high grain yield to suit for scanty rain fall areas. However, in contrast to this, Patel et al. (1980) and Rizwan Haris (2001) observed significant positive correlation between days to 50 flowering and grain yield. Simultaneously Days to maturity negative correlation helps to select the early maturing genotypes with high grain yield. The results are represented in the table 2 .

Path analysis: Path analysis partitions the total correlation coefficient into direct and indirect effects and measures the relative importance of the causal 
factor individually. In the present study, days to maturity $(\mathrm{Pgi}=+0.1391, \mathrm{Ppi}=+0.1539)$, panicle length $(\mathrm{Pgi}=+0.2843, \mathrm{Ppi}=+0.1516)$ and 1000 grain weight (Pgi $=+0.4621$, Ppi $=+0.3085)$ had showed positive direct effect on grain yield at both genotypic and phenotypic levels. For panicle length findings are in tune with Iyanar et al. (2001) reported direct effect for1000 grain weight, Patil et al. (2009) reported direct effect for days to $50 \%$ flowering, Warkad et al. (2010) reported direct effect for panical length, and Mahajan et al. (2011) also reported direct effect for panical length. Hence, panicle length may directly contribute for increasing yield also it indicates that selection can be performed for this trait in order to increase with grain yield and selection can be performed for 1000 grain weight trait in order to increase with grain yield. The results of direct and indirect effects on grain yield at genotypic level are represented in the table 3.

Whereas, plant height (Ppi $=+0.0858$, Pgi $=-0.0133$ ) had showed positive direct effect at phenotypic level and negative direct effect at genotypic level on grain yield. Hence, plant height may indirectly contribute for increased yield. The results of direct and indirect effects on grain yield at phenotypic level are presented in the table 4 .

The characters viz., days to $50 \%$ flowering $(\mathrm{Pg}=-0.1145$, $\mathrm{Ppi}=-0.0788)$, panicle width $(\mathrm{Pgi}=-0.0702, \mathrm{Ppi}=-0.1387)$ and stem girth $(\mathrm{Pgi}=-0.2550, \mathrm{Ppi}=-0.0050)$ had showed negative direct effect on grain yield at both genotypic and phenotypic levels. These results are in line with Warkad et al. (2010) reported negative direct effect for stem girth, Vijaya kumar et al. (2012) reported negative direct effect for days to $50 \%$ flowering and Arunkumar (2013) reported the same for days to $50 \%$ flowering and stem girth. Either too early or too late to flowering may decrease the yield levels of sorghum. Hence breeder has to decide the optimum time of flowering which commensurate with sorghum grain yield. However, panicle width and stem girth may not be important criteria for selection to improve the crop yield.

The characters, panicle width and 1000 grain weight had shown positive indirect effect with grain yield through positive and negative directions of days to $50 \%$ flowering $(\mathrm{Pgi}=+0.0003, \mathrm{Ppi}=+0.0016)$, days to maturity (Pgi=-0.0264, Ppi=-0.0047), stem girth (Pgi=$0.0127, \mathrm{Ppi}=-0.0022)$, plant height $(\mathrm{Pgi}=-0.0039$, $\mathrm{Ppi}=-$ $0.0006)$, panicle length (Pgi=-0.0897, $\mathrm{Ppi}=-0.0545$ ). Whereas, for 1000 grain weight through positive and negative directions of days to $50 \%$ flowering (Pgi $=+0.1145$, Ppi $=+0.0175)$, days to maturity $(\mathrm{Pgi}=-$ $0.0987, \mathrm{Ppi}=-0.0036)$, stem girth $(\mathrm{Pgi}=+0.1202$, Ppi $=$ $+0.0095)$, plant height $(\mathrm{Pgi}=+0.1027, \mathrm{Ppi}=+0.0825)$ panicle length $(\mathrm{Pgi}=-0.0621$, Ppi $=+0.0585)$ and panicle width (Pgi=-0.1479, Ppi= $=0.0483$ ) at both genotypic and phenotypic level.

Whereas, days to $50 \%$ flowering had shown negative indirect effect with grain yield positive direction through panicle length $(\mathrm{Pgi}=+0.0093, \mathrm{Ppi}=+0.0010)$, panicle width $(\mathrm{Pgi}=+0.0005, \mathrm{Ppi}=+0.0010)$ and negative direction through days to maturity ( $\mathrm{Pgi}=-$ $0.0041, \mathrm{Ppi}=-0.0840)$, stem girth $(\mathrm{Pgi}=-0.0356, \mathrm{Ppi}=$ 0.0094), plant height ( $\mathrm{Pgi}=-0.0061, \mathrm{Ppi}=-0.0150)$ and 1000 grain weight $(\mathrm{Pgi}=-0.0198, \mathrm{Ppi}=-0.0054)$ both at genotypic and phenotypic level.

Other characters viz., stem girth, panicle length had shown positive indirect effect with grain yield at genotypic level and days to maturity had negative indirect effect with grain yield at phenotypic level.

\section{Conclusion}

From the results of this study, it could be concluded that there were most of the traits evaluated were positively associated among themselves and could be improved simultaneously. It further concluded that characters such as panicle length, 1000 grain weight, days to maturity and stem girth had higher correlation and direct effect on grain yield. Therefore, due consideration should be given to these characters, while planning a breeding strategy for increased yield per plant.

\section{REFERENCES}

Arun kumar, B., (2013). Genetic variability, character association and path analysis studies in sorghum (Sorghum bicolor L. Moench). The Bioscan., 8(4): 1485-1488

Dewey, D.R. and Lu, K.H. (1959). A correlation and path coefficient analysis of components of crested wheatgrass seed production. Agronomy Journal, 51: 515-518

Ezeaku, I.E., Gupta, S.C. and Prabhakar, V.R. (1997). Classification of sorghum germplasm accessions using multivariate methods. African Crop Science Journal, 7:97-108

Falconer, D.S. (1981). Introduction to quantitative genetics. Second Edition. Longman, New York.

F.A.O.S.T.A.T. (2014). world sorghum production and utilization. FAO, Rome.

Iyanar, K., Gopalan, A. and Ramasamy, P. (2001). Correlation and path analysis in sorghum. Ann. Agric. Res., 22 (4): 495-497

Kengra, R. A., Tenkouano, A., Gupta, S.C. and Alabi, S. O. (2006). Genetic and phenotypic association between yield component in hybrid sorghum (Sorghum bicolor (L.) Moench) populations. Euphytica, 150:319-326

Khaled, A. G. A., Aml A. Tag El-Din and Eatemad, M. Hussein, (2014). Correlation, Path Analysis and RAPD Markers in Sorghum (Sorghum bicolor L. Moench) Genotypes. Assiut J. Agric. Sci., 45(4):15-28

Mahajan, R .C., Wadikar, P. B., Pole, S. P. and Dhuppe, M. V. (2011). Variability, Correlation and Path Analysis Studies in Sorghum. Research Journal of Agricultural Sciences , 2(1): 101-103

Muhammad, B., Rao, S. S. and Sahib, K. H. (2000). Correlation studies between the plant characters and shootfly resistance in sorghum. Crop Res., Hisar, 19(2):366-367.

Patel, R. H., Desai, K. B., Raj, K. R. V. and Parikh, R. K., (1980b). Estimates of heritability and genetic advance and other genetic parameters in an $\mathrm{F}_{2}$ populations of 
sorghum. Sorghum Newslett., 23:22-23

Patil, S. L., Sheelavantar, M. N. and Lamani, V. K. (2009). Correlation analysis among growth and yield components of winter sorghum, IS $M N$, 44: 14-17

Prabhakar, K. M. (2001). Variability, heritability, genetic advance and character association in rabi sorghum. $J$. Maharashtra Agric. Univ., 26: 188-189

Rizwan Haris M., (2001). Estimation of genetic diversity in germplasm collections of rabi sorghum (Sorghum bicolor L. Moench). M.Sc. (Agri.) Thesis, Univ. Agric. Sci., Dharwad, Karnataka (India). pp. 26- 80.

Singh, R.K. and Chaudhary, D.D. (1977). Biometrical methods in quantitative genetics analysis. Kalyani publishers, New Delhi. 318 pp.

Umakanth, A. V., Madhusudhana, R., Latha., K. M., Rafiq,
S. M. and Kiran, V. S. S., (2005). Analysis of genetic variation and trait interrelationships in sorghum [Sorghum bicolor (L.) Moench]. National J. Pl. Improv., 6(2): 104-107

Vijaya Kumar. N., Reddy, C . V. C. and Reddy. P .V. R. M. (2012). Path analysis among rabi sorghum genotypes (sorghum bicolor (L) moench). Plant Archives, 12(2): 959-960

Warkad, Y. N., Tidke. R. T., Maske, N. M., Kharde, A.V., and Potdukhe, N. R. (2010). Character association and path analysis in sorghum (Sorghum bicolor L. Moench). Inter. J. of Agric. Sci., 1(6): 100-104

Wright, S. (1921). Correlation and causation. Journal of Agricultural Research, 20:202-209 